In cooperation with the Putnam County Department of Planning and Development

\title{
Graphical Viewer for Displaying Locations and Logs of Selected Wells and Test Holes in Putnam County, New York
}

By Stephen W. Wolcott

\section{Introduction}

Aquifers (water bearing geologic units) are the primary source of drinking water in most of Putnam County, N.Y. The principal sources of data used to define the geometry and hydraulic characteristics of aquifers are the logs of wells and test holes within the county. This report explains how to use a graphical viewer, available on the World Wide Web (http://ny.water.usgs.gov/pubs/of/of051198), to locate selected wells and test holes in Putnam County and display their logs.

\section{Ground-Water Concepts}

Ground water is that part of precipitation that infiltrates through the unsaturated zone to the water table, which is the upper boundary of saturated material within an aquifer. Aquifers can occur in either unconsolidated deposits or bedrock. Aquifers in unconsolidated deposits consist of permeable, granular material such as sand or gravel. Ground water in unconsolidated aquifers is stored in, and flows through, the spaces or voids of the saturated unconsolidated material. Ground water in bedrock aquifers is stored and moves through secondary features such as fractures and faults. The composition of aquifer material determines the amount of ground water that can be stored and the rate at which it flows. The type of material, its extent, and its hydraulic properties determines the characteristics of the aquifer (Heath, 1983; and Waller, 1988).

An aquifer's transmissive properties depend on the hydraulic gradient which is the difference in water level (commonly referred to as head) over a given distance. Ground water moves at rates ranging from several feet per day to a few feet per year and flows from areas of recharge (high head) towards points or areas of discharge (low head). Precipitation that infiltrates the land surface is generally the major source of recharge for most aquifers. Areas of natural discharge are typically streams, rivers, lakes, and wetlands. Pumped wells are points of induced discharge where withdrawals are made for consumptive or industrial purposes. Ground-water discharge also occurs through evapotranspiration, which is greatest during the growing season (Heath, 1983; and Waller, 1988). A typical ground-water 
flow system under nonpumping conditions is illustrated in figure 1, which depicts the movement of ground water moving from the water table through an unconsolidated aquifer and bedrock aquifer and discharging to a nearby stream.

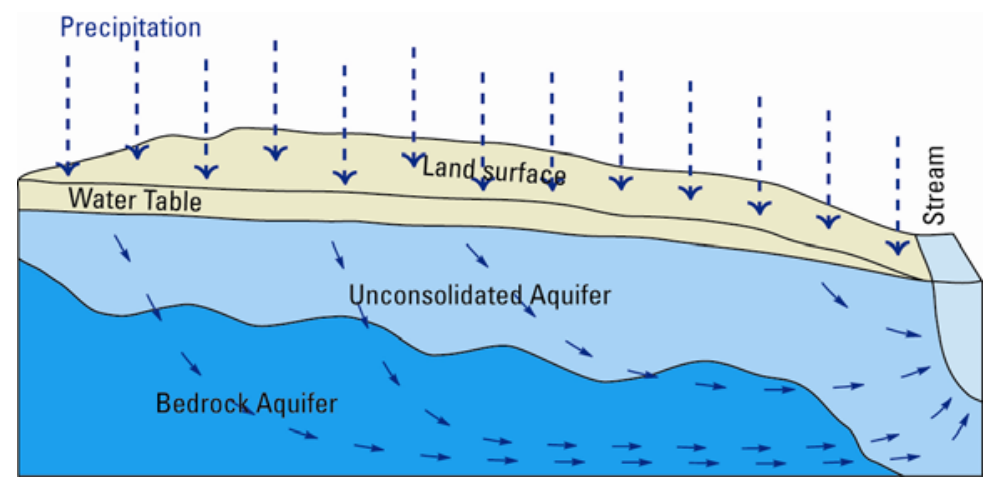

Figure 1. - Ground water movement through an unconsolidated aquifer and bedrock aquifer, under nonpumping conditions, showing movement from recharges areas to discharge areas.

A natural water budget of an aquifer system is of limited value for determining sustainability of long-term groundwater withdrawals. A common myth is that ground-water withdrawals are considered "safe" when they do not exceed the rate of recharge to the aquifer system. However, pumping withdrawals may alter other components of the water budget and decrease ground-water movement to areas of discharge, possibly causing adverse hydrological effects such as decrease streamflow and lowering water tables (Alley and others, 1999). Some typical effects of pumping on the movement of ground water in an aquifer are illustrated in figure 2. Under nonpumping conditions, most ground water flows to the stream (see fig. 1), whereas pumping intercepts some of the water that would reach the nearby stream and may induce flow from the nearby stream and lower the water table.

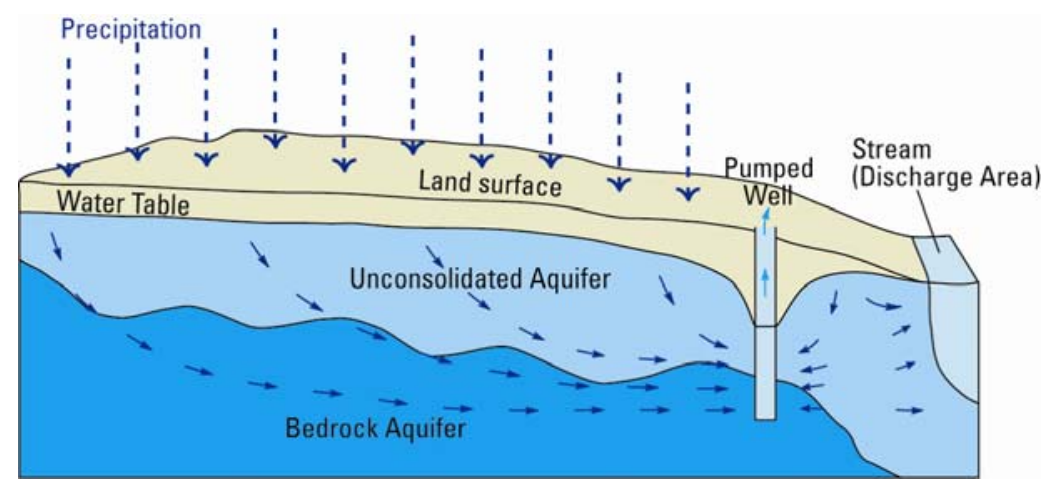

Figure 2. - Ground water movement through an unconsolidated aquifer and bedrock aquifer with a pumped well showing interception of water from a nearby stream. 


\section{Sources of Well Data used in Graphical Viewer}

Data used in the viewer are from the logs of wells and test holes that have been provided by three government agencies. A well is a drilled hole used for water supply, whereas a test hole is typically a drilled hole used for water or geotechnical exploration. The first set of data was provided by the Putnam County Department of Health (PCDOH), which was assembled and compiled as part of their well-log program (Anne Bittner, Putnam Count Department of Health, written commun., 2002). Most of the well logs represent privately owned domestic-supply wells, although some represent publicsupply wells. The PCDOH files, currently represent 6,500 wells and test holes, the majority of which can be accessed by the graphical viewer. The indicated locations of $\mathrm{PCDOH}$ wells are based on county tax-parcel maps. Most wells generally are at the centroids of the parcels; therefore, the locations of the wells displayed from this data source should be considered approximate. The accuracy of a location is a function of the size of the tax parcel; in general, the smaller the tax parcel, the more accurate the location of the well.

The second set of well and test-hole data that was compiled by the U.S. Geological Survey (USGS) and is stored in the National Water Information System (NWIS). Most of the data were collected during the 1950s and are included in a USGS report on Putnam County ground-water resources (Grossman, 1957); these data are also used in a later USGS report that identifies regional sources of ground water in southeastern New York State (Perlmutter, 1960). Other Putnam County data have been added to the NWIS data base since these two reports, including well and aquifer-test data collected in 1991 in the Town of Carmel. The entire NWIS data set contains records from about 1,200 wells and test holes in addition to information on about 20 springs. The locations of most wells, test holes, and springs in the NWIS data base were estimated from topographic maps, and therefore are considered approximate.

The third and smallest data set is from the New York State Department of Environmental Conservation's (NYSDEC) Water Well Program and currently represents about 75 well and test holes. Recent New York State legislation now requires that a permit be secured before well drilling can proceed and that a well-completion report must be supplied to the NYSDEC upon completion of a well or test hole. The report must includes a sketch map locating the well, and, if possible, latitude and longitude coordinates (D. Kendall, New York State Department of Environmental Conservation, written commun., 2003).

\section{Maps used in Graphical Viewer}

Three types of maps are provided as a base on which the locations of the wells and test holes can be displayed. The first type is USGS topographic maps (1:250,000, 1:100,000, and 1:24,000 scale) which are automatically displayed according to the level of detail selected; for example 1:250,000 scale which means that one foot shown on the viewer map equals 250,000 actual feet on the ground. A map at this scale will show far less local detail than a map of the same area at 1:24,000. A hill-shading option that gives the topography a three-dimensional appearance is also available.

The second and third types of maps are two types of geologic maps, developed at the 1:250,000 scale by the New York State Geological Survey (NYSGS) and show the distribution of the surficial geology (Cadwell and others, 1986) and bedrock geology (Fisher and others, 1970). All geologic contacts and features are approximate when displayed at the $1: 100,000$ and $1: 24,000$ scales. 


\section{Graphical Viewer Applications}

The viewer described here was designed to (1) display any area of interest in Putnam County on a topographic or geologic map, at a desired scale; (2) display well or test-hole locations on the desired map, and (3) display logs or completion reports of the selected wells or test holes.

The following sections provide a tutorial explaining how to use the graphical viewer as modified for Putnam County. This tutorial is not intended to be a comprehensive guide for all applications but rather an introduction to the process of selecting and displaying well and test-hole locations and logs. The user is encouraged to follow the steps outlined below. Then explore independently the many search and retrieval options that are available. The graphical viewer was developed from ESRI's ARC IMS* geographical information system. The following tutorial contains four sections: (1) Displaying an area of interest, (2) displaying well and test-hole locations, (3) displaying a well or test-hole log or completion report, and (4) viewing the surficial or bedrock geology maps.

* Use of a trade, product or firm names in this publication is for descriptive purposes only and does not imply endorsement by the U.S. Government.

\section{Displaying an Area of Interest}

Step 1 - Using an internet browser with access to the World Wide Web, connect to graphical viewer link http://ny.ims.er.usgs.gov/website/putnam/index.htm. The home (default) page of the viewer is shown in Figure 3 which depicts the political boundaries of Putnam County and its and towns, on a 1:250,000-scale New York State Department of Transportation (NYSDOT) topographic base with associated hill shading. Clicking the full-window option (the box next to the red " $\mathrm{X}$ " in the upper-right corner of the active window screen) will maximize the screen size of the map and provide the clearest detail.

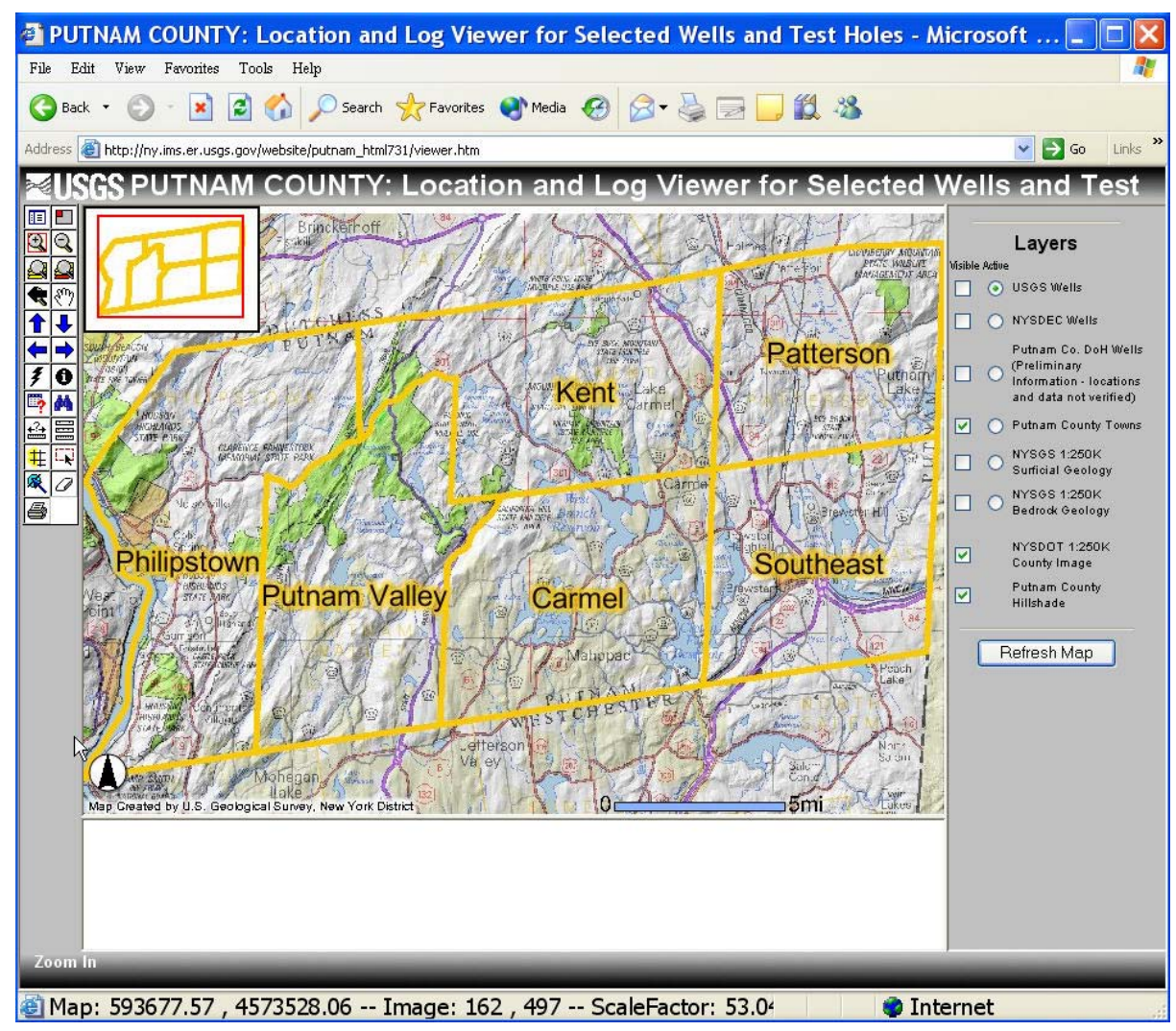

Figure 3 -- The home page of the Putnam County graphical viewer. 
Step 2 - Refer to the option bar on the left side of the map. An explanation of symbols in the option bar is provided in figure 4. The default option is "Zoom In". Two other options are used in this tutorial, "Select by Rectangle” and "Zoom to Full Extent”. Note the locations of these options for future steps.

\begin{tabular}{|c|c|c|}
\hline Toggle Between Legend and Layer List & 国国品 & Toggle Overview Map \\
\hline Zoom In & @ $Q$ & Zoom Out \\
\hline Zoom to Full Extent & $\Leftrightarrow 0$ & Zoom to Active Layer \\
\hline Back to Last Extent & 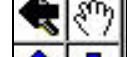 & Pan \\
\hline Pan to North & 它|r|r & Pan to South \\
\hline Pan to West & $\Rightarrow \Rightarrow$ & Pan to East \\
\hline Hyper Link & 31 & Identify \\
\hline Query & 国? & Find \\
\hline Measure & 热 & Set Units \\
\hline Buffer & \# $-\mathrm{E}-\mathrm{k}$ & Select by Rectangle \\
\hline Select by Line / Polygon & 20 & Clear Selection \\
\hline Print & 㫮 & \\
\hline
\end{tabular}

Figure 4. -- The options bar with an explanation symbols. Boldface denotes an option used in this tutorial.

Step 3 - A detail map is obtained by the following. (1) Select the "Zoom In" icon from the options bar. (2) Left click on any point of interest and hold the button down. This point will be the northwest corner of the area on interest. (3) Next draw a box around the area of interest by pressing and holding the left button of the mouse or touch pad and drag the cursor southeastward until the desired area has been outlined. (4) Release the mouse button.

Step 4 - An example of the resulting view is shown in figure 5. The scale of the map will be either 1:250,000, 1:100,000, or $1: 24,000$, depending on the size of the area that was outlined. Outlining only a small area will result in a 1:24,000 scale topographic base map. Repeat step 3 until the desired area has been outlined. The scale of the map that was selected for the example remained at 1:250,000. 


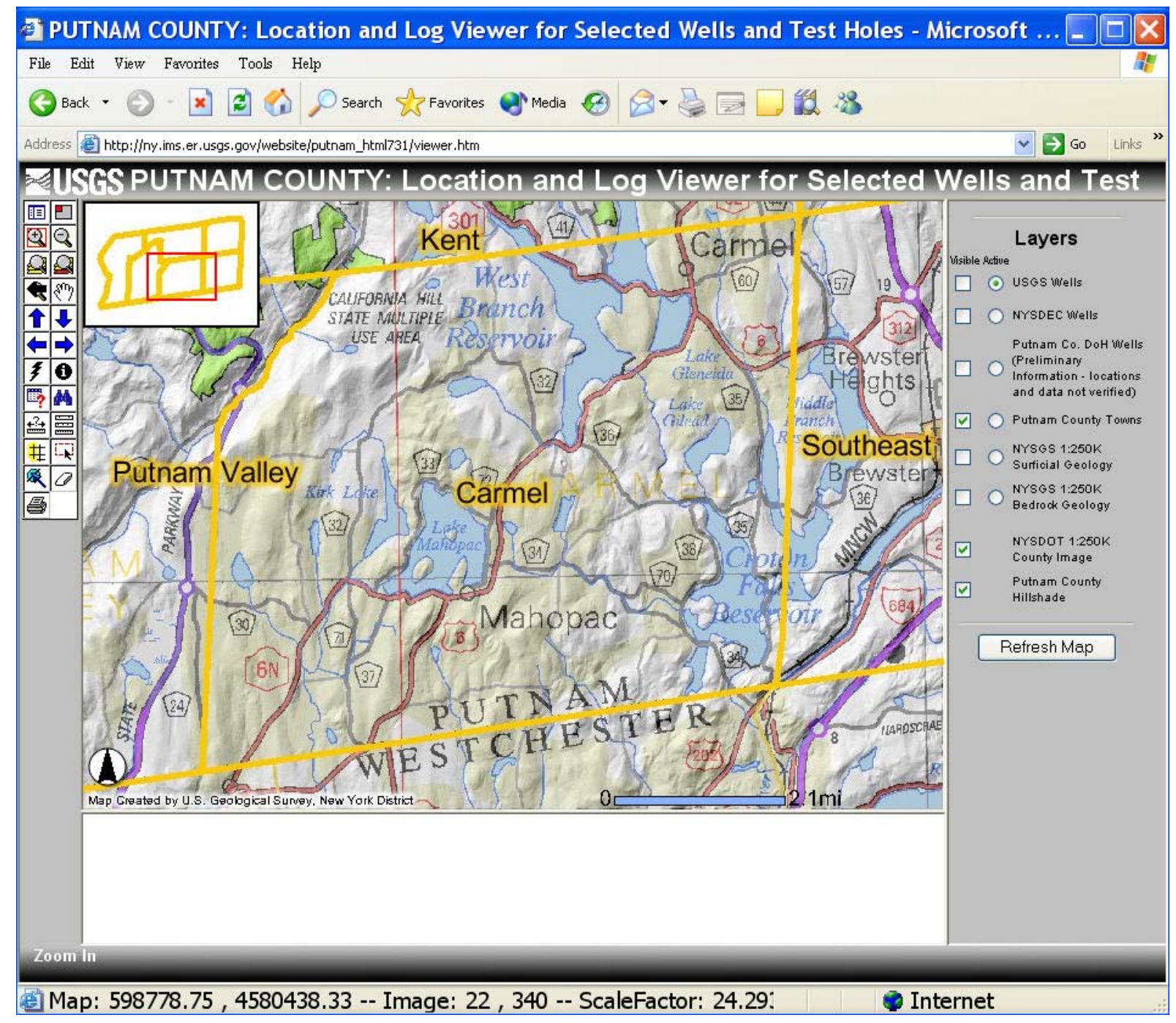

Figure 5. -- The screen as it appears after selection of a small area in the Town of Carmel.

Step 5 - Revert to the previous map by clicking on the "Back to Last Extent" option on the option bar (figure 4). This option is helpful if the user either misses the target area or wishes to select a different area. The "Zoom to Full Extent" option will cause the home page screen shown in figure 3 to reappear, providing an opportunity to restart the process.

Step 6 - Either begin the process again, or select a different area using the "Zoom to Full Extent" option and repeating steps 3, 4 , and 5 . 


\section{Displaying Well and Test Hole Locations}

Step 1 --After selecting an area the user can display the well and test hole locations. Refer to the "Layers" explanation on the right side of the map and the appropriate boxes in the column labeled "Visible" to select wells from the desired government agency.

Step 2 - Press the "Refresh Map" button at the bottom of the "Layers" explanation. The result (figure 6) shows the visible USGS and NYSDEC wells within the selected area.

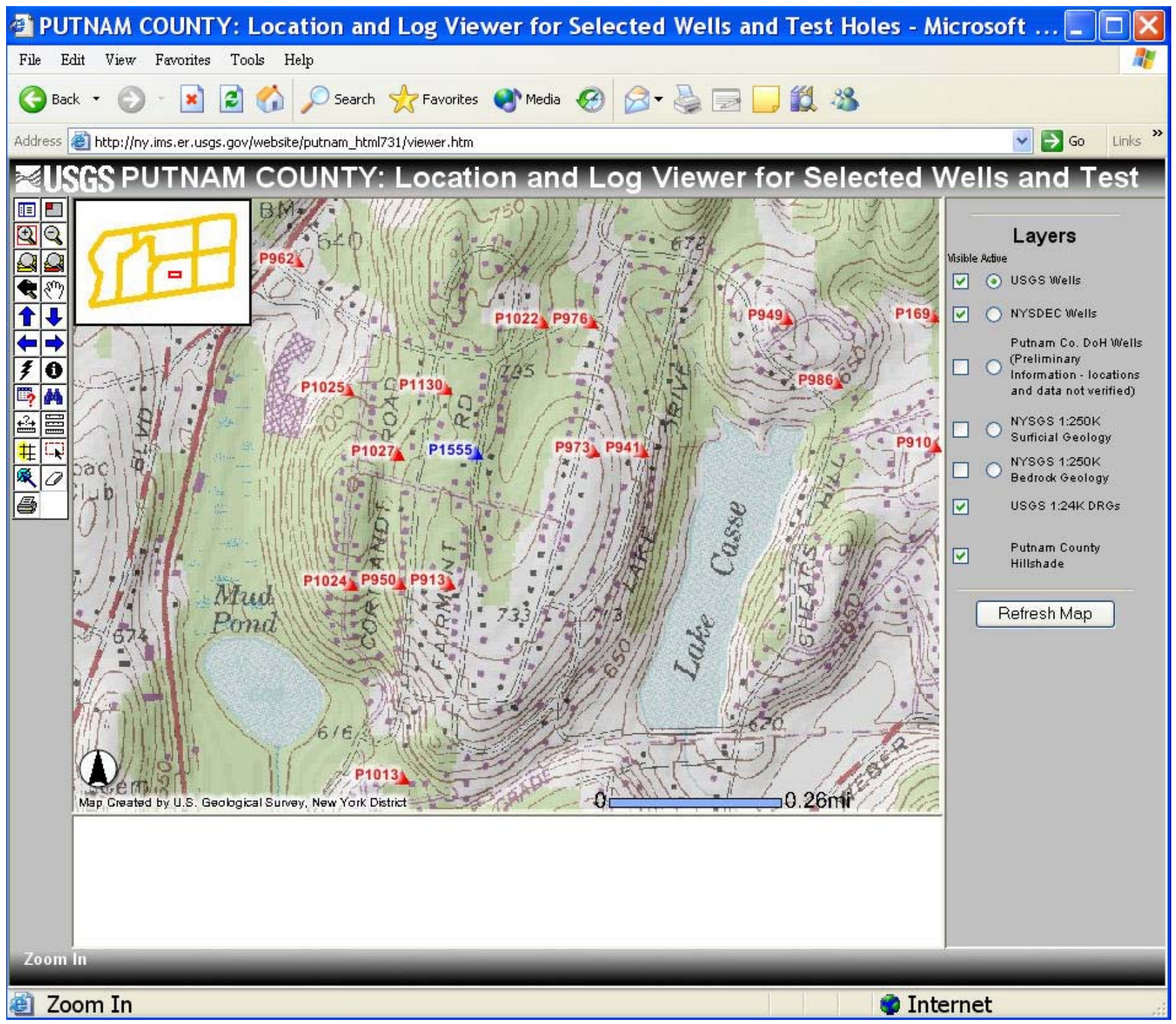

Figure 6. - Screen as it appears after selection of an area at a scale appropriate for locating a well or test hole. The scale for this display is $1: 24,000$. 


\section{Displaying a Well or Test-Hole Log or Completion Report}

Step 1 -- Select the area and the scale suitable that provides sufficient detail for displaying the well or wells in question by following the steps outlined in section 1 ("Displaying an Area of Interest”).

Step 2 - Display the wells as described in section 2 ("Displaying Well and Test Hole Locations"). In the "Layers" explanation at the right side of the map check the box in the column labeled "Visible" and also check the "Active" circle option for the governmental agency wells of choice. Choosing the "Active" option links the user to the log. Now click the "Refresh Map" at the bottom of the "Layers" explanation to show all selected wells or test-hole locations.

Step 3 --Choose the "Select by Rectangle" button from the option bar (see fig. 4). Left click and hold the mouse button down and drag a box around the well or wells of interest. The viewer will automatically refresh, as shown in figure 7. This example shows a 1:24,000 scale topographic base map with NYSDEC well P1555 selected. The blue triangle that represents this well (see fig. 6), is now partly obscured by a yellow dot, which indicates that the log or other information associated with this well has been selected. A link to the well completion report is seen in the "WELL_LOG" column of the "NYSDEC Wells" table below the map.

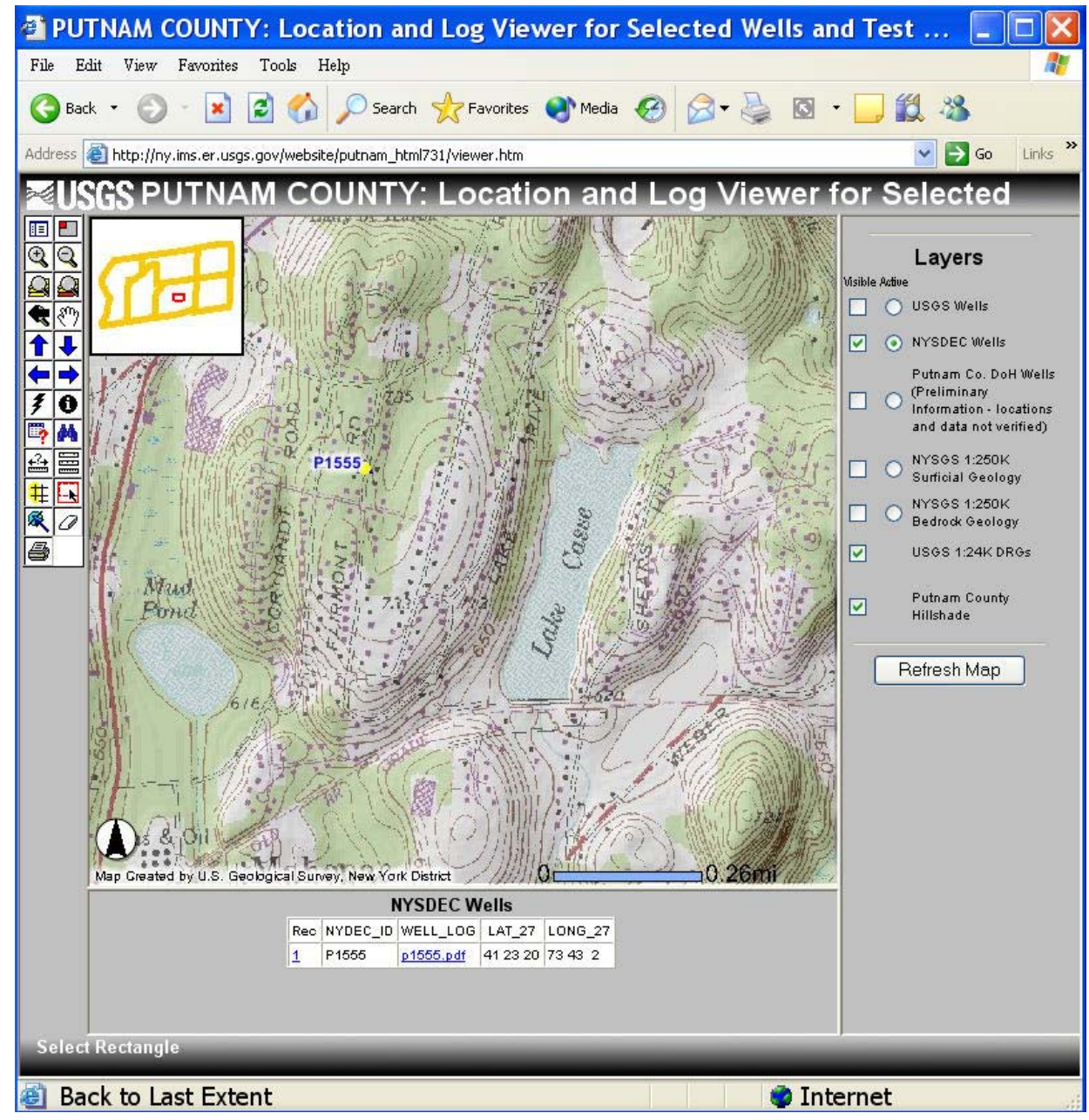

Figure 7. -- A 1:24,000-scale map showing location of well P1555 through the option "Select by Rectangle" and a link to the well's data (blue and underlined at the base of the map). 
Step 4 - Click on the blue link labeled "p1555.pdf" in the table to display scanned or numerical data for the selected well. The first of four pages of the NYSDEC well-completion report for this well is shown in figure 8.

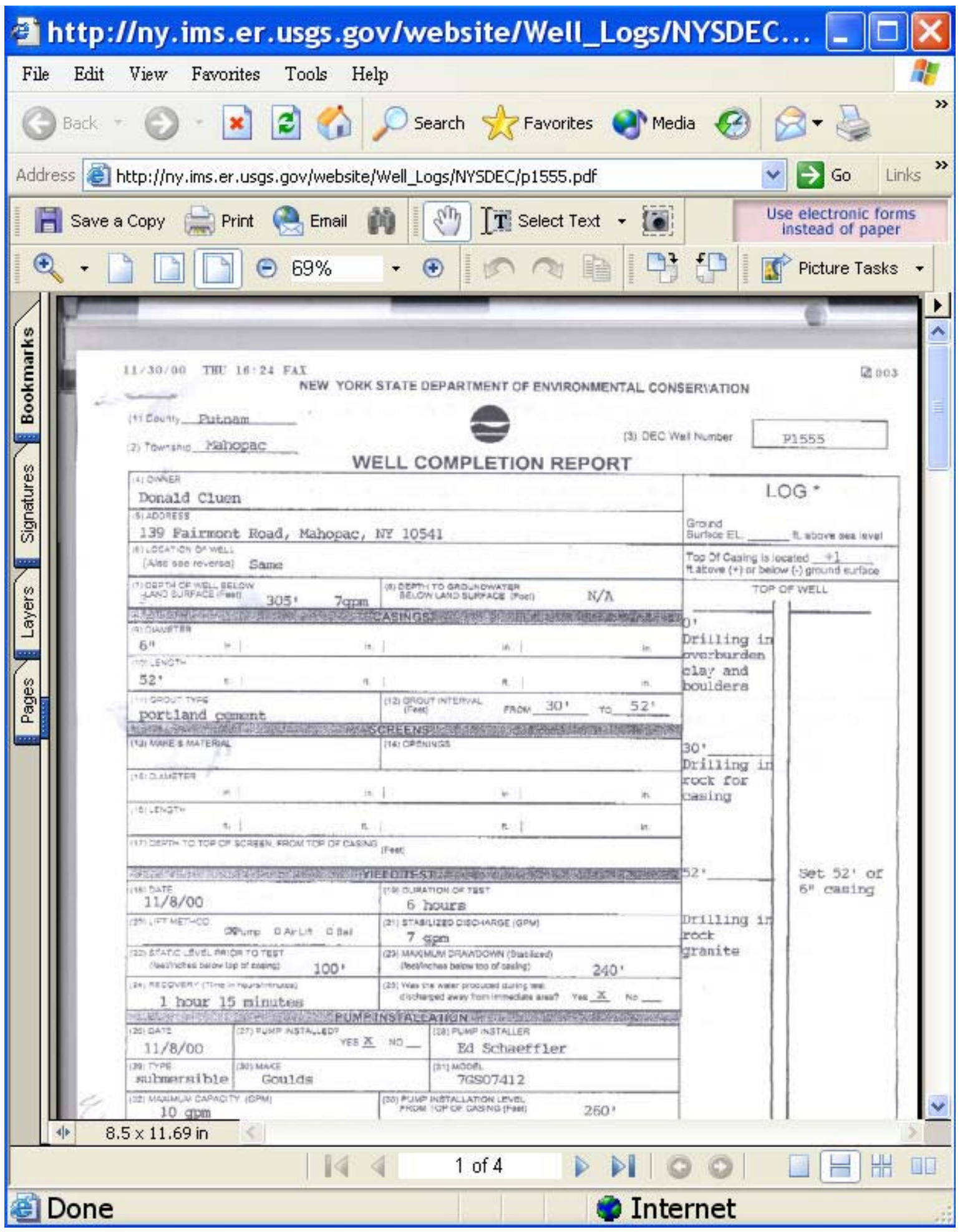

Figure 8. - The first of four well completion pages for NYSDE well P1555. 


\section{Viewing the Surficial or Bedrock Geology Maps}

The graphical viewer includes an option to superimpose on the topographic base map either the surficial geology or bedrock geologic maps at the 1:250,000 scale. The surficial geology map indicates the types of unconsolidated material and the location of undifferentiated bedrock where it crops out at the land surface; the bedrock geology map indicates the major types of metamorphic or sedimentary bedrock that occur in Putnam County.

Step 1 -- Select the “Zoom to Full Extent” option in the option bar on the left side of the map (fig. 4). The home page screen (fig. 3.) will appear.

Step 2 - In the "Layers” explanation on the right side of the map, locate the "NYSGS 1:250K Bedrock Geology”, and select the "Visible" and "Active" columns

Step 3 - Select the "Refresh Map" button at the bottom of the "Layers" explanation. The revised map with bedrock geology superimposed on the topographic base will appear (fig. 9). Links to the map explanation are shown in blue in the "LEGEND" column of the table of the bottom of fig 9 . 


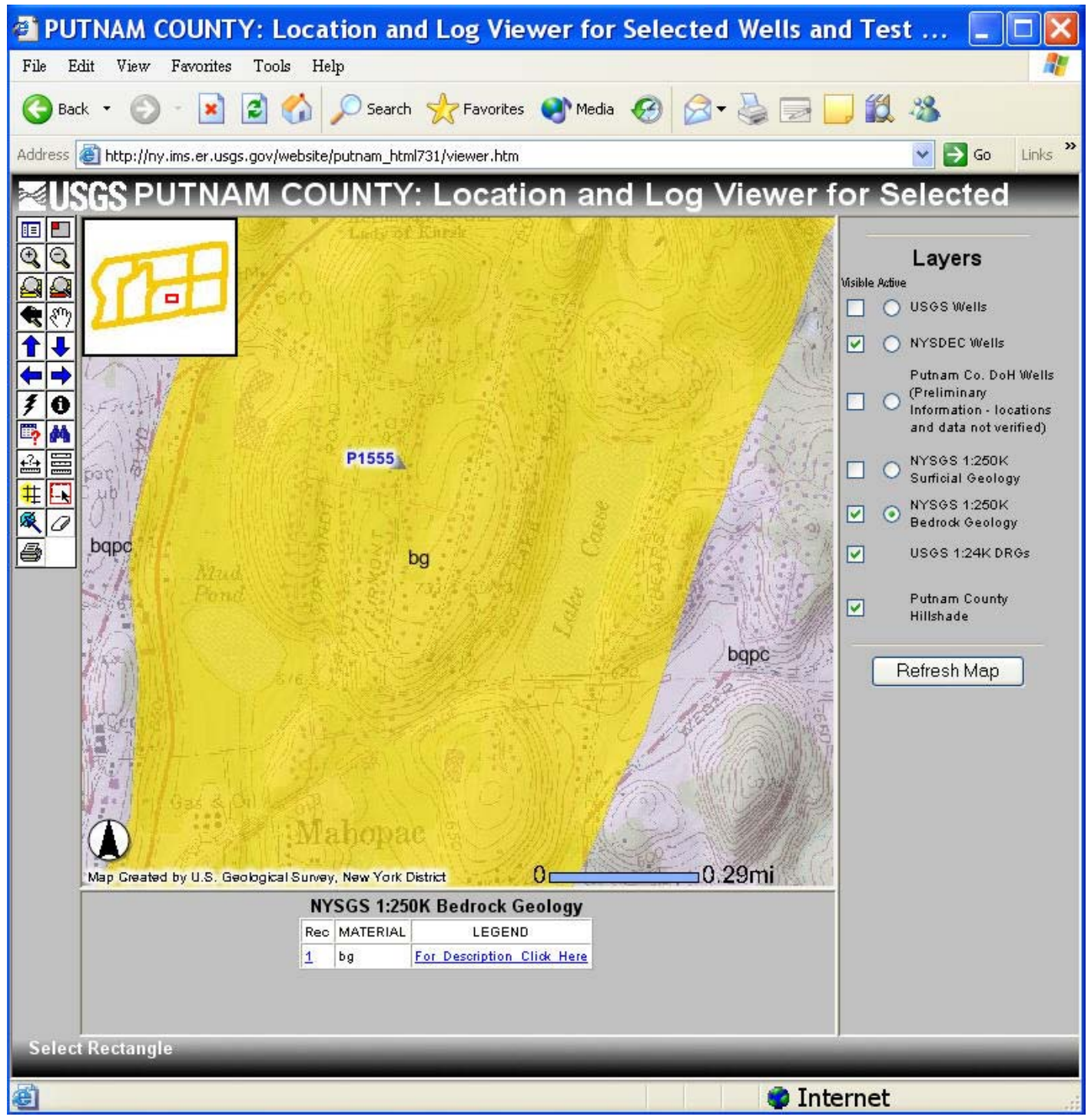

Figure 9. - Screen as it appears after selection of bedrock geology base at 1:250,000 scale. 


\section{Acknowledgements}

This graphical viewer was developed in cooperation with the Putnam County Department of Planning and Development Special thanks are extended to John Lynch, Lauri Taylor (Putnam County Soil and Water Conservation District) Andrew Labruzzo (Albany County Department of Economic Development, Conservation, \& Planning) for their patience and persistence. Thanks are also extended to Anne Bittner (Putnam County Department of Health) and Daniel Kendall (New York State Department of Environmental Conservation, Division of Water, Water Well Program) for access to their agencies data.

\section{References Cited}

\section{Ground-Water Concepts}

Alley, W.M., Reilly, T.E., and Franke, O.L., 1999, Sustainability of ground-water resources: U.S. Geological Survey Circular 1186, 79 p. http://water.usgs.gov/pubs/circ/circ1186/

Heath, R.C., 1983, Basic ground-water hydrology: U.S. Geological Survey Water-Supply Paper 2220, 84 p. http://water.usgs.gov/pubs/wsp/wsp2220/

Waller, R.M., 1988, Ground water and the rural homeowner: U. S. Geological Survey Booklet, 37 p. http://water.usgs.gov/pubs/gip/gw_ruralhomeowner/index.html

\section{Data Sources}

Cadwell, D.H., Connally, G.G., Dineen, R.J., and others, 1986, Surficial geologic map of New York: New York State Museum, Geological Survey, Map and Chart Series no. 40, Lower Hudson Sheet, scale 1:250:000.

Fisher, D.W., Isachsen, Y.W., and Rickard, L.W., 1970, Geologic map of New York: New York State Museum and Science Service, Geological Survey, Map and Chart Series Number 15, Lower Hudson Sheet, scale $1: 250: 000$.

Grossman, I.G., 1957, The ground-water resources of Putnam County, N.Y.: New York State Department of Conservation, Water and Power Control Commission, Bulletin GW-7, 78 p.

Perlmutter, N.M., 1960, Sources of ground water in southeastern New York: U.S. Geological Survey Circular 417, 9 p. 


\section{Selected Links of Interest on World Wide Web}

Adobe link to free "Acrobat Reader". http://www.adobe.com/products/acrobat/readstep.html

ESRI's link to ARC IMS. The parent software from which the viewer application was developed. http://www.esri.com/software/arcims/index.html

Leggette, Brashers, and Graham, Inc., Professional ground-water and environmental engineering services, home page.

http://lbgweb.com

Location and Log Viewer for Selected Wells and Test Holes in Putnam County. http://ny.water.usgs.gov/pubs/of/of051198

New York State Department of Environmental Conservation, Division of Water, home page. http://www.dec.state.ny.us/website/dow/index.html

New York State Department of Environmental Conservation, Division of Water, Water Well Program, home page. http://www.dec.state.ny.us/website/dow/driller_ext.html

New York State Geological Survey, home page. http://www.nysm.nysed.gov/geology.html

Putnam County Department of Planning and Development, home page. http://www.putnamcountyny.com/planning/planning.html

Putnam County Department of Health, home page. http://www.putnamcountyny.com/healthdept/healthdept.html

Putnam County Soil and Water Conservation District, home page. http://www.putnamcountyny.com/soilandwater/soilandwater.html

Topozone.com, home page. A World Wide Web application for determining the latitude and longitude for a given point using 1:200,000 through 1:25,000 scale base maps. http://www.topozone.com

U.S. Geological Survey, New York District, home page with link to electronic version of this report. http://ny.water.usgs.gov

U.S. Department of the Interior

U.S. Geological Survey

For Additional Information Contact:

U.S. Geological Survey

425 Jordan Road

Troy, NY 12180-8349

(518) 285-5600
Open File Report 2005-1198

January 2005

This report and additional earth science information can be found on the World Wide Web at http://ny.water.usgs.gov 